\title{
English Grammatical Problems of Chinese Undergraduate Students
}

\author{
Juan Bao \& Jing Sun \\ Foreign Language Department, Liaoning Technical University \\ 47 Zhong Hua Road, Fuxin, Liaoning 123000, China \\ Tel: 86-418-665-0721Ｅ-mail: baojuan766@126.com
}

\begin{abstract}
Grammar teaching and learning is necessary in foreign language teaching. However, its function and method have been argued for decades. In the average teaching process in China, teachers divide grammar teaching into four stages: a) Presentation; b) Isolation and explanation; c) Practice; and d) Test. There are problems existing in grammar teaching in China now, including the inconsistence between the goal of teaching and real classroom teaching, ignorance of teachers and learners, inappropriate textbooks, and negative learning attitudes. According to a research on 10 English teacher and 30 undergraduate students in mainland China, the paper reports some conclusions and implications on grammar teaching in classroom. First, understanding students' attitudes is a key factor in teaching. Second, grammatical rules should be presented and explained implicitly in certain contexts. Third, students' involvement needs to be increased. Finally, more real communicative activities are effective in class.
\end{abstract}

Keywords: Grammar teaching, CLT, Attitude, Grammatical problem

\section{Introduction}

Marianne Celce-Murcia (1985) maintained that noticing and persuasive evidences show that no-grammar teaching will lead to the product of clumsy and impropriate foreign languages, which means that grammar teaching is essential for language teaching. However, teachers have argued for several decades about the function and the method of grammar teaching in foreign language teaching (FLT) in China. Grammar teaching and learning is necessary in FLT. As Ur (1988a) puts it "You cannot use words unless you know how they should be put together." For the past decades, English grammar teaching in China has been dominated by the traditional grammar-translation approach. Marianne (1979a) concluded as follows: 1) Classes are taught in the mother tongue, with little active use of the target language; 2) Long elaborate explanations of the intricacies of grammar are given; 3) Grammar provides the rules for putting words together, and instruction often focuses on the form and inflection of words; 4) Often the only drills are exercises in translating disconnected sentences from the target language into the mother tongue. 5) Little or no attention is given to pronunciation. It holds true in Chinese grammar teaching. As a result, the traditional method produced unsatisfactory teaching results and students lacked the ability to speak and understand English.

In the average teaching process in China, teachers divide grammar teaching into four stages: a) Presentation; b) Isolation and explanation; c) Practice; and d) Test.

a) Presentation. The aim of the presentation is to get the learners to perceive the structure-its form and meaning - in both speech and writing and to take it into short-term memory (Ur, 1988b). Teachers often read aloud the dialogue or the short story in the textbook, and then the students are asked to read, repeat, or retell. Teachers will ask students to make sentences with the pattern drills learnt.

b) Isolation and explanation. According to Ur, the objective is that the learners should understand these various aspects of the structure. At this stage, teachers focus on the grammatical items: the form, the meaning, the function, and the rules.

c) Practice. ... whose aim is to cause the learners to absorb the structure thoroughly; or, to put it another way, to transfer what they know from short-term to long-term memory (Ur, 1988b). At this stage, teachers design a series of exercises for classroom practice, or home assignments, this can make the learners absorb the grammar rules completely.

d) Test. The main objective of tests within a taught course is to provide feedback, without which neither teacher nor learner would be able to progress very far. We have to know where we are in order to know there to go next (Ur, 1988c). A test is a good way to check whether the students have mastered the grammar rules they have been learning. It is also an evaluation of teachers' work.

\subsection{Introduction of Communicative Language Teaching Method}

In the 1980s, communicative language teaching method (CLT) was introduced into China. That was a great 
transformation in grammar teaching in China. Furthermore, the New Curriculum Standard was invented in 2001, requiring more attention to the use of grammar rules in certain situations, and stressing the meaning of sentence function, not just the patterns. Students' ability to speak and listen has been improved. However, some teachers and schools believe it is useless to teach grammar. They simply avoid explaining the rules in their teaching, leading to a decline in students' abilities to read and write.

In the eyes of Sandra J.S.(2002), center of CLT is the understanding of language learning as both an educational and a political issue. It is interpreted that language teaching is inextricably linked with language policy. Language learning goals and teaching strategies should vary according to the specific contexts. Therefore, program design and implementation depend on negotiation between policy makers, linguists, researchers, and teachers.

\section{The Current Situation}

There are problems existing in grammar teaching in China now.

First of all, the goals of grammar teaching CLT cannot be realized in the classroom. The goal is to enable students to communicate in the target language (Diane,2000a). But in real classroom teaching, the goal becomes to help students get high marks.

Second, after the rise of CLT, grammar teaching was ignored by some linguists. Some instructors maintained that it was not necessary to teach grammar. So many teachers abandon teaching grammar. As a result, the students have made rapid progress in speaking and listening more than before, but their written English still lacks accuracy.

Third, the current textbook is not appropriate. In any language teaching-learning situation, success depends on giving proper consideration to both human elements, and also to the non-human elements such as the textbook, the syllabus...(Marinne, 1979b). With the invention of New Curriculum Standard, most textbooks have been changed to meet the need of CLT. They focus on communicative ability, while in real classroom teaching, grammar still is the focus.

Lastly, students hold negative attitudes towards grammar learning. Many students feel grammar teaching has little effect on students' practical ability to use English, especially in listening and speaking. They think the presentation and explanation of grammar rules in class are dull and less motivated.

What then is the current situation? Do students regard grammar as something they only need to review before their exams, so they can get higher marks?

The authors of this article undertook a small study to find out the attitudes and teachers towards grammar, students' and teachers' practice in grammar learning and teaching, and their attitudes towards the grammatical knowledge in textbooks.

\section{Method}

The participants of this research included student participants and teacher participants. All the participants are from one technical university in China. All the student participants are freshmen majoring in engineering. The teacher participants are those teachers who teach the freshmen.

The primary instruments were questionnaires and a writing task. The questionnaires for this research comprised a questionnaire for students and one for English teachers. The questionnaires were written in Chinese to avoid any misunderstandings by the subjects.

The questionnaires were distributed to 10 English teachers and 30 students. One of the English teachers explained the purpose of the research, and guided the students to give true responses to those questions. The students spent no more than 10 minutes accomplishing the questions and 15 minutes to finish the writing assignment.

All 10 teachers and 30 students handed back the questionnaire. Among them, all questionnaires for teachers, but only 26 questionnaires for students were valid, because four students selected all the choices, or made the same choice for every question.

\subsection{Results from the questionnaire}

As a whole, most of the students (56\%) and teachers (71\%) thought that grammar plays an important role in the mastery of English.

From their response, $41.6 \%$ students and most of the teachers $(78 \%)$ agreed that the amount of grammar in the textbook was suitable. We also learnt that $38.4 \%$ students thought that there was too much grammar in the 
textbook. Very few students $(18 \%)$ and teachers $(6 \%)$ though the grammatical knowledge in the textbook is not enough.

Most of the students $(89 \%)$ and nearly more than $90 \%$ teachers agreed that teachers emphasize grammar teaching in class. This tells us that most of the teachers emphasize grammar teaching in practice.

Interestingly, most students thought their teacher often uses deductive ways to explain grammar rules, while most teachers thought they often applied inductive ways to teach grammar. They held different ideas about the same question.

Most students thought their teacher corrected the errors in their oral English immediately, while more than half of the teachers chose they corrected afterwards. This tells us that the teachers' evaluation of their teaching practice does not agree with their real practice in class.

Most teachers said they collected all kinds of errors in students' composition and corrected them in front of the whole class while most students reflected that teachers only made a mark where there were mistakes.

At the same time, $79 \%$ students thought their weakness in learning grammar was that they can neither memorize the grammatical rules nor apply them in a correct way. As for the teacher participants, half of them thought students failed to memorize and apply, and half thought their students failed to apply them in a correct way.

\subsection{Analysis of the written task}

As EFL teachers, we encounter many errors particularly the verb from when marking the students' written work, because in the Chinese language, the verb forms do not change to indicate tense or personal forms. These are indicated by other words by the context. Therefore, the students always feel confused when writing in English. They tend to associate and use the Chinese grammatical patterns to write in English.

We collected 26 compositions from freshmen, who had learned all the basic grammar rules in their middle school. They should have mastered a vocabulary of about 3000 words. They were asked to write a short paragraph, for which they were given the outline. When their work was collected, a number of problems came to sight. They are shown in Table 1. Examples of the errors are shown in appendix A.

As may be seen from the table, the most frequent error was the incorrect use of the modal verb. Other frequent errors included misuse of tense, confusion of verbs and nouns, and mismatching or loss of prepositions. On the other hand, there were not many errors in confusion of active voice and passive voice and misuse of infinite clauses.

\section{Conclusion}

Correctly understanding students' attitudes towards grammar is a key factor in teaching. With the development of the communicative approach, some teachers think that teaching grammar is old-fashioned and that present English teaching should aim at developing students' speaking and listening ability. These Chinese teachers have not captured the real meaning of the communicative approach. CLT does not exclude grammar teaching; instead CLT aims broadly to apply theoretical perspectives of the Communicative Approach by making communicative competence the goal of language teaching and by acknowledging the interdependence of language and communication (Diane, 2000b).

Grammatical rules help students to understand and use the target language better, if they are presented and explained implicitly in certain contexts. That is to say, the students are first presented with the target grammar items in context. Under the instruction of teachers, the students can deduce the grammar usage from the context, and then apply the rules to real situations.

In addition, the teachers should increase and encourage students' involvement. This could be done, for example, through classroom discussion, speech contests, establishing English corner, form an English club, etc. Common forms of classroom activities like problem-solving activities will encourage students to talk and discuss the problem to find a solution. Discussions and debates can take learners one step further. They can provoke spontaneous fluent language use by learners when they exchange opinions. Role-play can be process-oriented group or pair technique, which is effective for practicing doing things in the target language. All these suggested activities provide an appropriate platform for the students to communicate in English. In such an environment, students may have low anxiety, good self-confidence and high motivation. In short, the teacher makes his lesson amusing, stimulating and challenging, so that students are fully engaged during the whole lesson. At the same time, we need to bear in mind that discourse learnt by students cannot be separated from comprehension and expression. Students should therefore be encouraged to focus on the whole material rather than on separated forms. 
Finally, it should be pointed out that the more real communicative activities are, the better and more effective the classes will be. We have to consider how we can make formal instruction help students use the language correctly and appropriately.

\section{References}

Diane L.F. (2000). Techniques and principles in language teaching. Oxford: Oxford University Press. p128(a); 121 (b)

Marianne Celce-Murcia. (1979). Teaching English as a second or foreign language. Massachusetts: Newbury House Publishers, Inc. p3 (a); 302 (b)

Marianne Celce-Murcia. (1985). Making informed decisions about the role of grammar in language teaching. TESOL Newslette, 19(1), 4-5

Sandra J.Savignon.(2002). Interpreting Communicative Language Teaching, London: Yale University Press. 4

Ur Penny. (1988a), Grammar practice activities: a practice guide for teachers. London: Cambridge University Press. p. 4(a); 7(b); 9-10 (c)

\section{Appendix: Examples of the errors in the writing task}

1. Modal verbs

(1) Modal verb + past tense

We must spent more time on reading.

I need took my first English class.

(must spend)

Nothing can broke us...

(need take)

(2) Modal verb + doing

You can repeating...

(can break)

So I must hard studying.

(can repeat)

(3) Modal verb + to do

I must to learn.

(must study hard)

You should to speak English.

(must learn)

(4) Modal verb + nouns/prepositions

We must success.

(should speak)

I should through...

(must succeed)

2. Tense

(1) be + verb

Although we are now stay way...

(are staying)

(2) Different tenses in one sentence

It opened my eyes, and make me know some...

(opened my horizon, and made...)

(3) Confusion of tenses

They are don't in book...

(are not)

We are like a family, we live more happy then. (lived)

He speak it.

(spoke)

I was never saw...

(I have never seen...)

3. confusing verbs and nouns

When I accessed to ...

(got access to...)

Now I successed come to the ...

(succeeded in coming)

4. Mismatching or losing of prepositions

I listen English...

(listen to)

I was satisfied middle school...

(was satisfied with) 
How to buy a phone card in abroad...

After reaching at the post office...

I spend most time to playing...

If I spend time play like this...

I didn't good at English...

5. Misuse of infinite clauses

The first thing is make sure...

The last thing you should do is pay for...

Study English have no easy way.

6. Confusion of active voice and passive voice

The first thing I did was recited..

...until you are paid for the card. (abroad)

(reaching)

(spend...playing)

(spend...playing)

(was not good at)

(is to make sure)

(is to pay for)

(studying English)

(was to recite)

(you paid)

Table 1. Categorized mistakes in students' compositions

\begin{tabular}{l|ll}
\hline Categories of mistakes & Times & Frequency \\
\hline Modal verbs & 15 & $37.5 \%$ \\
Tense & 8 & $20 \%$ \\
Confusing verbs and nouns & 2 & $5 \%$ \\
Misuse or not using a required preposition & 10 & $25 \%$ \\
Misuse of infinite clauses & 3 & $7.5 \%$ \\
Confusion of active voice and passive voice & 2 & $5 \%$ \\
\hline
\end{tabular}




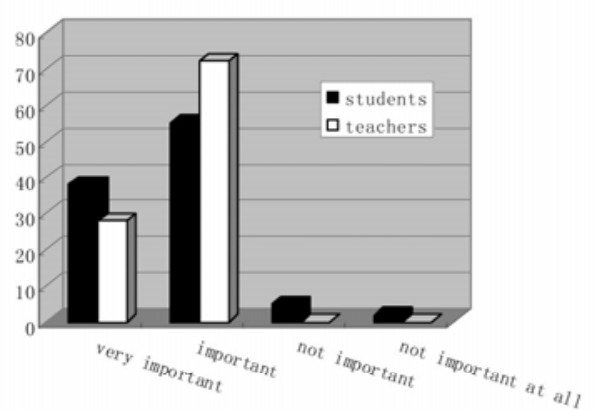

Figure 1. The attitudes of students and teachers towards grammar

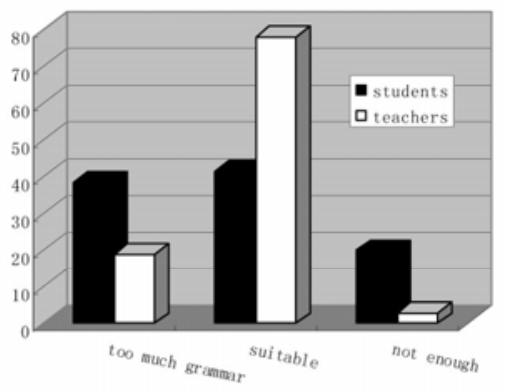

Figure 2. The attitudes of students and teachers towards grammatical knowledge in the text

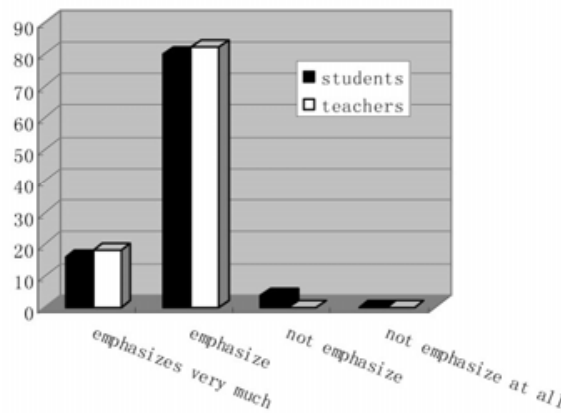

Figure 3. Students' and teachers' practice in grammar learning and teaching

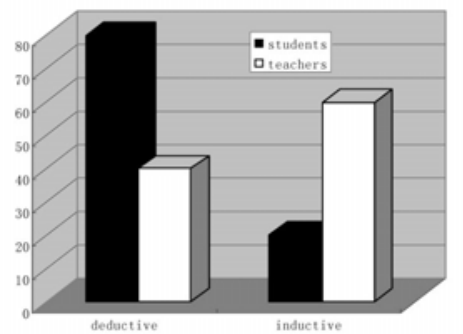

Figure 4. Teachers' way of explaining grammar

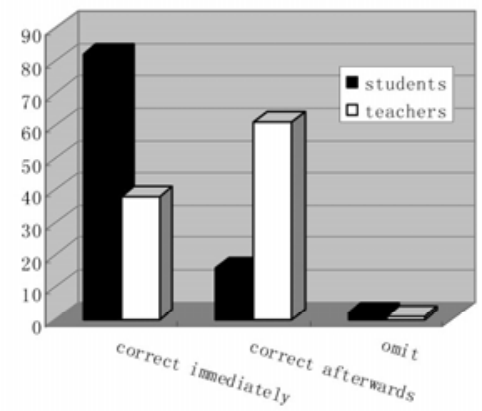

Figure 5. Teachers' way of correcting errors

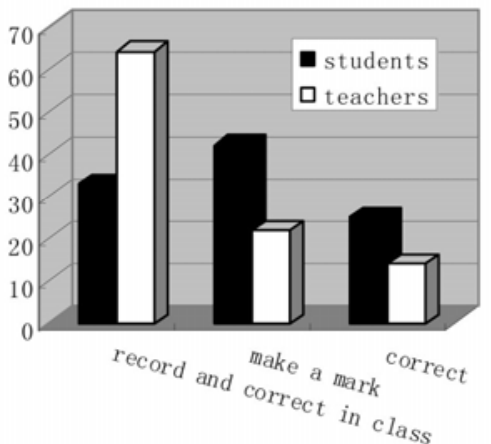

Figure 6. Teachers' way of marking students' composition

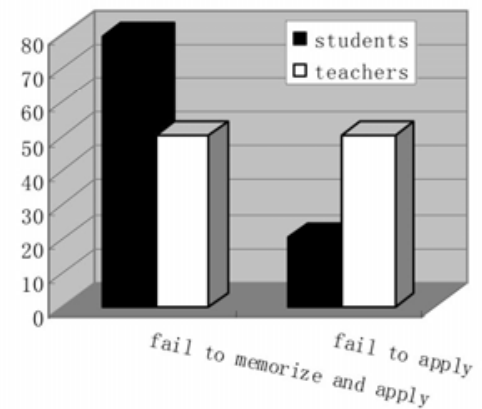

Figure 7. Students' weakness in learning grammar 